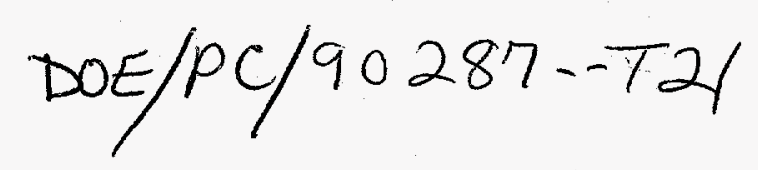

\title{
OXIDATION OF COAL AND COAL PYRITE MECHANISMS AND INFLUENCE ON SURFACE CHARACTERISTICS DE-FG22-90PC90287
}

\author{
Fiona M. Doyle \\ University of California at Berkeley \\ Dept. of Materials Science and Mineral Engineering
}

TECHNICAL PROGRESS REPORT (August 31, 1995)

\section{RESEARCH OBJECTIVES}

The objective of this research is to develop a mechanistic understanding of the oxidation of coal and coal pyrite, and to correlate the intrinsic physical and chemical properties of these minerals, along with changes resulting from oxidation, with those surface properties that influence the behavior in physical cleaning processes.

Work during the final quarter has been directed at completing outstanding areas of work. The Master's thesis of Donna L. Bodine, which includes the work reported in the last three quarterly reports, was completed and filed during the quarter. The enclosed manuscript, "Treatment of aqueous streams containing strong oxidants using bituminous coal" has been prepared for inclusion in the proceedings of the Engineering Foundation Conference on Technological Solutions for Pollution Prevention in the Mining and Mineral Processing Industries. The meeting was held in Palm Coast, Florida in January 1995, but when the PI gave the talk it became apparent that there were a few additional studies that should be done to strengthen the work. This included a brief study of the interaction of Upper Freeport coal with $\mathrm{Cr}(\mathrm{VI})$, which is summarized here. Finally the possibility of using coal for treating commercial effluents containing toxic metals has been considered. Although this is outside of the scope of work of the current grant, it represents work done by Ms. Bodine while supported by a State of California Minority Fellowship. This slant enhances the work done under the grant, and is summarized here for the sake of completeness.

\section{EXPERIMENTAL METHODS AND RESULTS}

\section{a. Coal Sample}

Upper Freeport coal from the Troutville \#2 Mine, Clearfield County, Pennsylvania was used in this study. Table I shows the composition of this sample. The coal was stored under argon after mining to prevent oxidation, and was ground in a ball mill and sieved. The $+250-200$ mesh $(63-75 \mu \mathrm{m})$ size fraction was stored under argon for use in this work. 
Table I: Proximate, Sulfur, and Oxygen Group Analysis of Upper Freeport Coal Sample

\begin{tabular}{|c|c|c|c|c|c|c|c|c|c|}
\hline \multirow[t]{2}{*}{ Origin } & \multirow[t]{2}{*}{ Rank } & \multicolumn{4}{|c|}{$\begin{array}{l}\text { Proximate } \\
\text { (As-rec'd, \%) }\end{array}$} & \multicolumn{2}{|c|}{$\begin{array}{l}\text { Sulfur Forms } \\
-(d r y, \%)\end{array}$} & \multirow{2}{*}{$\begin{array}{c}\text { Wt\% } \\
\text { Phenolic } \\
\text { oxygen, } \\
\text { As-rec'd }\end{array}$} & \multirow{2}{*}{$\begin{array}{c}\text { Wt } \% \\
\text { Carboxyl } \\
\text { oxygen, } \\
\text { As-rec'd } \\
\end{array}$} \\
\hline & & Ash & $\begin{array}{l}\text { Volatile } \\
\text { Matter }\end{array}$ & $\begin{array}{c}\text { Fixed } \\
\text { Carbon }\end{array}$ & Moisture & Pyritic & Total & & \\
\hline $\begin{array}{l}\text { Upper } \\
\text { Freeport } \\
\text { Penn. }\end{array}$ & $\begin{array}{l}\text { MV } \\
\text { Bituminous }\end{array}$ & 17.59 & 27.05 & 55.35 & 1.50 & 0.66 & 1.12 & 0.68 & 1.01 \\
\hline
\end{tabular}

\section{b. Oxidation by $\mathrm{Cr}(\mathrm{VI})$}

We have used potassium permanganate fairly extensively as a chemical oxidant, in an attempt to simulate accelerated weathering of coal. Our results (reported previously) have unequivocally demonstrated that coal might be used as a reducing agent to treat effluents and process streams that cannot be discharged to ground and surface waters because they contain oxidants. $\operatorname{Cr}(\mathrm{VI})$ is a powerful oxidant whose release is closely regulated because of its inherent toxicity and carcinogenicity. Activated carbon has been shown to be an effective reducing agent for $\mathrm{Cr}(\mathrm{VI}){ }^{1}$ Accordingly, we performed exploratory tests to determine how effective Upper Freeport coal might be in reducing $\mathrm{Cr}(\mathrm{VI})$ to the less hazardous $\mathrm{Cr}(\mathrm{III})$, and in removing $\mathrm{Cr}$ from solution.

$10 \mathrm{~g}$ samples of Upper Freeport coal were stirred for 4 hours with $100 \mathrm{ml}$ of dilute $\mathrm{K}_{2} \mathrm{CrO}_{4}$ solution at $\mathrm{pH} 2.5$ and 5 . The suspensions were then filtered under vacuum, and the filtrate was analyzed using a Perkin Elmer $\mathbf{3 1 1 0}$ atomic absorption spectrometer to determine the total chromium in solution. The color and color intensity of the filtrate were noted,

Table II presents the results of these preliminary studies. Although the individual species were not analyzed, the color after 4 hours, in conjunction with the Eh-pH diagram for the $\mathrm{Cr}_{-} \mathrm{H}_{2} \mathrm{O}$ system ${ }^{2}$, suggests that the $\mathrm{Cr}(\mathrm{VI})$ in the very dilute samples was completely reduced to $\mathrm{CrOH}^{2+}$. Reduction consumes hydrogen ions, as demonstrated in the following "model" reaction, which for simplicity shows $\mathrm{Cr}(\mathrm{VI})$ oxidizing elemental carbon to $\mathrm{CO}_{2}$. Clearly other oxidation chemistries are expected; this merely presents the extreme of complete oxidation:

$$
4 \mathrm{HCrO}_{4}^{-}+3 \mathrm{C}+12 \mathrm{H}^{+}=4 \mathrm{CrOH}^{2+}+6 \mathrm{H}_{2} \mathrm{O}+3 \mathrm{CO}_{2}
$$

The resulting increase in $\mathrm{pH}$ would favor precipitation of some $\mathrm{Cr}_{2} \mathrm{O}_{3}$. The yellow color of the more concentrated solutions indicates residual $\mathrm{Cr}(\mathrm{VI})$ using $10 \mathrm{~g}$ of coal to $100 \mathrm{ml}$ of solution. However, appreciable $\mathrm{Cr}$ was removed from solution, probably due to partial reduction of $\mathrm{Cr}(\mathrm{VI})$, and precipitation of $\mathrm{Cr}_{2} \mathrm{O}_{3}$. Although much more work is needed to quantify the ability of coal to reduce $\mathrm{Cr}(\mathrm{VI})$, these preliminary results demonstrate some capability that might be optimized with $\mathrm{pH}$ and Eh control.

1 Huang and Wu, Water Research, 11, 1977, 673-679.

2 D.G. Brookins, Eh-pH Diagrams for Geochemistry, Springer-Verlag, 1988. 
Table II: Effect of initial chromate concentration, $[\mathrm{Cr}(\mathrm{VI})]_{\mathrm{o}}$, and $\mathrm{pH}$ on total $\mathrm{Cr}(\mathrm{III})$ and $\mathrm{Cr}(\mathrm{VI})$ concentration, $[\mathrm{Cr}]_{\text {tot, }}$ after 4 hours treatment with Upper Freeport coal

\begin{tabular}{||c|c|c|c|}
\hline$[\mathrm{Cr}(\mathrm{VI})]_{0}(\mathrm{ppm})$ & $\mathrm{pH}_{0}$ & {$[\mathrm{Cr}]_{\text {tot }}(\mathrm{ppm})$} & Final color \\
\hline 1200 & 2.5 & 800 & yellow \\
\hline 1100 & 5.5 & 800 & yellow \\
\hline 18 & 2.5 & 17 & colorless \\
\hline 13 & 5.5 & 7 & colorless \\
\hline
\end{tabular}

\section{c. Sequential Contacting of Thermally Oxidized Upper Freeport Coal with $\mathbf{C u}^{2+}$}

Our May 31, 1995 report included the conclusion that the uptake of $\mathrm{Cu}^{2+}$ onto oxidized coal followed Freundlich isotherms, and that coal oxidized thermally or by $\mathrm{KMnO}_{4}$ approximated a Langmuir isotherm. Accordingly, coal that has equilibrated with a dilute $\mathrm{Cu}^{2+}$ solution should be capable of adsorbing more $\mathrm{Cu}^{2+}$ from a more concentrated solution. Such behavior would be central to the efficacy of a countercurrent system of contacting for maximizing metal uptake. Hence, a limited number of tests were done to evaluate the ability of oxidized Upper Freeport coal to adsorb successively increasing amounts of copper in sequential contacts. Thermally oxidized coal was selected, because adsorption isotherms, in conjunction with analysis of surface acid groups (as reported in our May 31, 1995 report), had shown that only this type of coal actually adsorbed a reasonable percentage of the total amount of metal that it could, in principle, take up. Thermally oxidized coal was contacted with $3.5 \mathrm{ppm} \mathrm{Cu}^{2+}, \mathrm{pH} 4$ solution, using a ratio of $10 \mathrm{~g}$ of

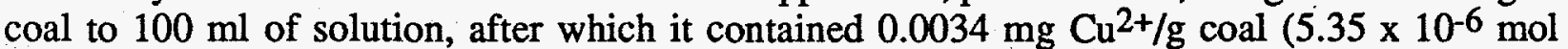
$\left.\mathrm{Cu}^{2+} / \mathrm{g}\right) .5 \mathrm{~g}$ portions of this pretreated coal were then contacted with either $374 \mathrm{ppm} \mathrm{Cu} \mathrm{Cu}^{2+}(5.9 \mathrm{x}$ $\left.10^{-3} \mathrm{M}\right)$ or $3617 \mathrm{ppm} \mathrm{Cu}^{2+}\left(5.7 \times 10^{-2} \mathrm{M}\right), \mathrm{pH} 4$ solutions. After both two and four hours of contact the copper uptake was assessed by analysis of the residual copper in solution.

The results are presented in Table III, which compares the actual loadings with the theoretical maximum predicted from the Langmuir isotherms (see May 31, 1995 report). The oxidized coal, with some copper already adsorbed on the surface, was clearly able to remove more copper from solution. However, even at the higher $\mathrm{Cu}^{2+}$ concentration, the copper loading was only half the theoretical maximum after four hours. The actual amount of copper on the coal was very small; indeed there was almost no upgrade associated with this step.

Table III: Copper loading (mol/g) on thermally oxidized coal already containing $5.35 \times 10^{-6}$ moles $\mathrm{Cu}^{2+} / \mathrm{g}$, after 2 and 4 hours of contact with $\mathrm{pH}_{4} \mathrm{CuSO}_{4}$ solutions and residual effluent concentrations

\begin{tabular}{|c|c|c|c|c|}
\hline $\begin{array}{c}{\left[\mathrm{Cu}^{2+}\right] \text { in }} \\
\mathrm{CuSO}_{4} \text { feed }\end{array}$ & $\begin{array}{c}\text { Contact } \\
\text { time }(\mathrm{hr})\end{array}$ & $\begin{array}{c}\text { Cu loading } \\
(\mathrm{mol} / \mathrm{g})\end{array}$ & $\begin{array}{c}\% \text { of max } \\
\text { loading }\end{array}$ & $\begin{array}{c}{\left[\mathrm{Cu}^{2+}\right] \mathrm{in}} \\
\text { effluent (ppn }\end{array}$ \\
\hline $5.9 \times 10^{-3} \mathrm{M}$ & 2 & $9.8 \times 10^{-6}$ & 12 & 312 \\
\cline { 2 - 5 }$(374 \mathrm{ppm})$ & 4 & $1.5 \times 10^{-5}$ & 22 & 277 \\
\hline $5.7 \times 10^{-2} \mathrm{M}$ & 2 & $2.7 \times 10^{-5}$ & 39 & 3444 \\
\cline { 2 - 5 }$(3617 \mathrm{ppm})$ & 4 & $3.6 \times 10^{-5}$ & 52 & 3391 \\
\hline
\end{tabular}




\section{POTENTIAL APPLICATION OF COAL FOR TREATING EFFLUENTS}

The objective of the entire study concluding this quarter has been to examine how coal, and coal pyrite are oxidized, and how oxidation affects their surface properties. In the course of this study, we have used numerous techniques, in an endeavor to accelerate natural weathering. Further, we have examined how oxidized coal interacts with metal ions, primarily to assess the complexing ability of functional groups generated by oxidation. This work on the adsorption of metal ions also provides relevant information for situations in which pyrite in coal releases acid, which then mobilizes toxic metal ions into the resulting acid rock drainage. Further, this work might provide useful information for addressing the emission of potentially hazardous air pollutants during combustion of coal containing trace metals; it is quite likely that the coal could undergo an acid leach stage before combustion.

There remains the intriguing possibility that coal might be used as a reducing agent or metal sorbent for treating a wide variety of effluents and process streams that originate outside of the power industry. Many process streams contain traces of toxic metal ions, and are particularly problematic if they also contain oxidizing agents. The discharge of such streams is highly regulated, but there is an urgent need for more cost-effective technology for achieving compliance.

The adsorption isotherms reported earlier, along with the results reported above for sequential contacting, indicate that although coal is capable of adsorbing ions, its capacity is too limited to warrant serious consideration as an economic or technically viable treatment option. Our metal uptake tests used one gram of coal to $10 \mathrm{ml}$ of solution, which is equivalent to $100 \mathrm{~kg} \mathrm{coal} / \mathrm{m}^{3}$ solution. This coal would not only have to be transported to the treatment site, but it would also require disposal. The only realistic strategy would be combustion for the purpose of generating electrical power, and this strategy would require precautions to ensure that no additional metals were emitted in flue gases, and that all leachable metals were removed from the ash phase. Furthermore, the residual concentrations of metal ions in equilibrium with coal are too high for compliance with most water quality regulations.

Coal is more promising as an inexpensive reducing agent for oxidized species. Permanganate is particularly easy to treat because it is easy to achieve an equilibrium potential and $\mathrm{pH}$ where a solid manganese-bearing species predominates, using coal alone. $\mathrm{Cr}(\mathrm{VI})$ is not quite as amenable to treatment, because it is reduced to a soluble species with coal alone. However coal might be used as a reducing agent, in conjunction with other reagents that could control $\mathrm{pH}$ to promote the formation of a solid $\mathrm{Cr}$ (III) species.

\section{PUBLICATIONS}

Donna L. Bodine, "Effect of Oxidation on the Removal of $\mathrm{Cu}^{2+}, \mathrm{Cd}^{2+}$ and $\mathrm{Mn}$ (VII) from Dilute Aqueous Solutions by Upper Freeport Bituminous Coal", M.S. Thesis, University of California at Berkeley, June, 1995

Fiona M. Doyle and Donna L. Bodine, "Treatment of aqueous streams containing strong inorganic oxidants using bituminous coal", Engineering Foundation Conference on Technological Solutions for Pollution Prevention in the Mining and Mineral Processing Industries, Palm Coast, Florida, January 22-27, 1995. 


\section{DISCLAIMER}

This report was prepared as an account of work sponsored by an agency of the United States Government. Neither the United States Government nor any agency thereof, nor any of their employees, makes any warranty, express or implied, or assumes any legal liability or responsibility for the accuracy, completeness, or usefulness of any information, apparatus, product, or process disclosed, or represents that its use would not infringe privately owned rights. Reference herein to any specific commercial product, process, or service by trade name, trademark, manufacturer, or otherwise does not necessarily constitute or imply its endorsement, recommendation, or favoring by the United States Government or any agency thereof. The views and opinions of authors expressed herein do not necessarily state or reflect those of the United States Government or any agency thereof. 